\title{
Productive performance and composition of milk protein fraction in dairy cows supplemented with fat sources ${ }^{1}$
}

\section{José Esler de Freitas Júnior ${ }^{2}$, Francisco Palma Rennó ${ }^{3}$, Marcos Veiga dos Santos ${ }^{3}$, Jefferson Rodrigues Gandra ${ }^{2}$, Milton Maturana Filho ${ }^{2}$, Beatriz Conte Venturelli ${ }^{4}$}

1 Pesquisa financiada pela FAPESP.

2 Programa de Pós-Graduação em Nutrição e Produção Animal da Faculdade de Medicina Veterinária e Zootecnia da Universidade de São Paulo - FMVZIUSP. Bolsista do CNPq.

${ }^{3}$ Departamento de Nutrição e Produção Animal da Faculdade de Medicina Veterinária e Zootecnia da Universidade de São Paulo - FMVZI USP.

4 Iniciação Cientifica do Departamento de Nutrição e Produção Animal da Faculdade de Medicina Veterinária e Zootecnia da Universidade de São Paulo - FMVZ/USP. Bolsista da FAPESP.

ABSTRACT - The objective of this study was to evaluate the use of fat sources in rations for lactating cows on the productive performance and composition of milk protein fraction. Twelve Holstein cows were used, grouped in three balanced $4 \times 4$ Latin squares, fed with the following rations: control; refined soybean oil; whole raw soybean; and calcium salts of unsaturated fatty acid (Megalac-E). Dry matter and nutrient intake, and daily milk production were evaluated. The samples used to analyze milk composition were collected in two alternate days and were obtained from two daily milking. Milk composition and total nitrogen, non-protein nitrogen and non-casein nitrogen ratios were analyzed. The casein, serum protein and true protein ratios were obtained by difference. Dry matter and nutrient intakes were lower when cows received the diet containing calcium salts of fatty acids, in relation to the control diet. Among the diets with fat sources, the one with whole raw soybean and calcium salts decreased milk production. There was no effect of fat sources added to the diet on crude protein, non-protein nitrogen, non-casein nitrogen, true protein, casein, casein/milk true protein ratio and serum protein. Similarly, the experimental diets did not influence the protein fractions when expressed in percentage of milk crude protein. The utilization of fat sources in diets changes milk production and composition of lactating cows, but does not influence the composition of milk protein fractions.

Key Words: fat supplementation, intake, milk production and composition, non-protein nitrogen, true protein

\section{Desempenho produtivo e composição da fração proteica do leite de vacas leiteiras sob suplementação com fontes de gordura}

RESUMO - Objetivou-se com este estudo avaliar a utilização de fontes de gordura em rações para vacas em lactação sobre o desempenho produtivo e a composição da fração proteica do leite. Foram utilizadas 12 vacas da raça Holandesa, agrupadas em três quadrados latinos balanceados $4 \times 4$, alimentadas com as seguintes rações: controle; óleo de soja refinado; grão de soja in natura; e sais de cálcio de ácidos graxos insaturados (Megalac-E). Avaliaram-se o consumo de matéria seca e de nutrientes, e a produção diária de leite. As amostras utilizadas para análise da composição do leite foram coletadas em dois dias alternados e foram provenientes das duas ordenhas diárias. Foram analisados a composição do leite e os teores de nitrogênio total, nitrogênio não-proteico e nitrogênio não-caseinoso. Por diferença, foram obtidos os teores de caseína, proteína do soro e proteína verdadeira. O consumo de matéria seca e de nutrientes foi menor quando as vacas receberam a ração contendo sais de cálcio de ácidos graxos em relação à ração controle. Entre as rações com fontes de gordura, aquela com grão de soja e sais de cálcio diminuiu a produção de leite. Não houve efeito das fontes de gordura adicionadas nas rações sobre os teores de proteína bruta, nitrogênio não-proteico, nitrogênio não-caseinoso, proteína verdadeira, caseína, relação caseína/proteína verdadeira no leite e proteína do soro. De forma semelhante, as rações experimentais não influenciaram as frações proteicas expressas em porcentagem da proteína bruta do leite. A utilização de fontes de gordura nas rações altera a produção e a composição do leite de vacas em lactação, mas não influencia a composição das frações proteicas do leite.

Palavras-chave: consumo, nitrogênio não-proteico, produção e composição do leite, proteína verdadeira, suplementação de gordura 


\section{Introduction}

The addition of fat to dairy cows diets can promote variable answers on milk yield and composition. Results found in the literature attribute these differences to the basal diet provided, specially the roughage, to the lactation stage and the energetic balance, and to the composition and quantity of the fat source used (NRC, 2001). According to Smith et al. (1993), the negative answers to the fat supplementation in diets for lactating cows occurs more often when corn silage is the single, or the main, roughage source.

Chilliard (1993) summarized various studies about fat supplementation for dairy cows and observed that, depending on the lactation phase in which the fat supplementation started, the increases in milk yield varied from 0.31 to $0.72 \mathrm{~kg}$ milk/cow/day. Staples et al. (2001) cited that the productive answer to the utilization of supplemental dietary fat for lactating cows can result in increases in milk yield from 2.0 to $2.5 \mathrm{~kg} / \mathrm{cow} /$ day.

Santos et al. (2009) evaluated the inclusion of 3.30\% soybean oil, in total dry matter basis, in the diet of dairy cows in the transition period and early lactation. The authors observed that the animals fed soybean oil diet produced $2.53 \mathrm{~kg} / \mathrm{d}$ more milk than those fed control diet (7.93\%).

The use of fat sources on dairy cows diets can also promote reduction in milk protein content, although the production of protein has not been influenced, and in some cases, even increased. This reduction can possibly occur by the simple effect of dilution due to the increase in production when fat sources are added to the diets (Garnsworthy, 2002), by variations in the concentrations of milk protein fractions, as casein concentration, or even by variations in some hormone concentrations that can promote physiological changes and affect milk protein synthesis (Wu et al., 1994).

Changes in dry matter intake represent one of the main factors related to the variation of results in studies evaluating fat supplementation on diets of lactating cows, especially when different fat sources are compared. According to Allen (2000), the type of supplemental fat source also influences intake alterations, with the calcium salts of fatty acids being considered the source of fat that most decrease this variable. Unprocessed fat sources can decrease intake by approximately $50 \%$ of the observed reduction when calcium salts of fatty acid are used, while the supplemental fat sources based on utilization of vegetable oils show alteration in dry matter intake lower than the one observed with the utilization of calcium salts. However, when there is reduction in intake and the magnitude of reduction is not sufficient to reduce the daily energy intake, negative answers in utilization of fat sources on lactating diets of lactating cows are not observed (Allen, 2000).

In this way, the objective of this study was to evaluate the utilization of fat sources on diets of lactating cows and their effects on productive performance and composition of milk protein fraction.

\section{Material and Methods}

The experiment was conducted at the Experimental Confinement Campus Hall Administrative Pirassununga, University of São Paulo.

Twelve Holstein cows averaging $580 \mathrm{~kg}$ live weight, 90 to 180 days of lactation and medium production of $25 \mathrm{~kg} / \mathrm{cow} /$ day were used. Cows were grouped in three balanced $4 \times 4$ Latin squares, in an experimental period of 19 days with 12 days of adaptation and 7 days of sample collection.

It was used the following diets, formulated according to NRC (2001): control - with $2.5 \%$ of ether extract (EE) in the dry matter; soybean oil - with 5.5\% of ether extract, obtained by inclusion of $3.0 \%$ of refined soybean oil in the concentrate; whole raw soybean, with $5.5 \%$ of ether extact, obtained by the inclusion of $16 \%$ of whole raw soybean in the concentrated; and calcium salts of unsaturated fatty acids (MEGALAC-E, Química Geral do Nordeste and Arm \& Hammer, Inc.) - with $5.5 \%$ of ether extract, obtained by the inclusion of $3 \%$ of calcium salts of unsaturated fatty acids in the concentrate. Corn silage was used as roughage during the experimental period, and the respective diets, water and mineral salt were supplied ad libitum.

The quantities of roughage and concentrate supplied as well as the orts of each experimental diet were weighed daily in order to estimate intake. The animals were fed according to the dry matter intake of the previous day, so to keep $5-10 \%$ of orts as not to limit intake. Samples of the supplied ingredients were collected and stored at $-20^{\circ} \mathrm{C}$ for later chemical analysis.

Supplied ingredients and ort samples were analyzed for dry matter (DM), organic matter (OM), mineral matter $(\mathrm{MM})$, ether extract (EE), crude protein (CP), neutral detergent insoluble nitrogen (NDIN), acid detergent insoluble nitrogen (ADIN) and lignin content (Tables 1 and 2), according to the methodologies described by Silva \& Queiroz (2002). The crude protein content was obtained by multiplying the total nitrogen ratio by 6.25 .

The neutral detergent fiber (NDF), neutral detergent fiber corrected for ash and protein (NDFap) and acid 
Table 1 - Concentrate composition on dry matter basis (\%DM)

\begin{tabular}{|c|c|c|c|c|}
\hline & \multicolumn{4}{|c|}{ Experimental diet } \\
\hline & Control & $\begin{array}{l}\text { Soybean } \\
\text { oil }\end{array}$ & $\begin{array}{l}\text { Whole } \\
\text { soybean }\end{array}$ & $\begin{array}{l}\text { Calcium } \\
\text { salts }^{1}\end{array}$ \\
\hline \multicolumn{5}{|l|}{ Ingredients (\%DM) } \\
\hline Ground corn & 52.14 & 45.00 & 44.57 & 45.00 \\
\hline Soybean meal & 39.10 & 39.10 & 8.60 & 39.10 \\
\hline Soybean oil & - & 7.14 & - & - \\
\hline Whole soybean & - & - & 38.10 & - \\
\hline $\begin{array}{l}\text { Calcium salts of unsaturated } \\
\text { fatty acids }\end{array}$ & - & - & - & 7.14 \\
\hline Urea & 1.74 & 1.74 & 1.71 & 1.74 \\
\hline Ammonium sulfate & 0.12 & 0.12 & 0.12 & 0.12 \\
\hline Sodium bicarbonate & 1.48 & 1.48 & 1.48 & 1.48 \\
\hline Magnesium oxide & 0.05 & 0.05 & 0.05 & 0.05 \\
\hline Mineral salts ${ }^{2}$ & 4.67 & 4.67 & 4.67 & 4.67 \\
\hline Limestone & 0.24 & 0.24 & 0.24 & 0.24 \\
\hline Salts & 0.48 & 0.48 & 0.48 & 0.48 \\
\hline \multicolumn{5}{|l|}{ Nutritional composition } \\
\hline Dry matter ${ }^{3}$ & 90.03 & 90.85 & 90.73 & 90.67 \\
\hline Organic matter & 87.92 & 88.03 & 88.11 & 86.27 \\
\hline Crude protein & 30.42 & 29.71 & 28.71 & 29.71 \\
\hline $\mathrm{NDICP}^{4}$ & 8.93 & 8.26 & 13.96 & 8.26 \\
\hline $\mathrm{ADICP}^{4}$ & 7.31 & 6.65 & 7.09 & 6.65 \\
\hline Ether extract & 2.96 & 9.74 & 7.82 & 8.34 \\
\hline Total carbohydrates & 54.54 & 48.58 & 51.58 & 48.22 \\
\hline Neutral detergent fiber & 15.51 & 14.46 & 19.55 & 14.46 \\
\hline NDFap $^{5}$ & 13.02 & 12.12 & 14.98 & 12.12 \\
\hline Non-fiber carbohydrates & 45.53 & 40.62 & 38.03 & 40.26 \\
\hline NFCap $^{5}$ & 48.02 & 43.10 & 42.60 & 42.96 \\
\hline Acid detergent fiber & 6.63 & 6.26 & 11.38 & 6.26 \\
\hline Lignin & 1.51 & 1.42 & 3.44 & 1.42 \\
\hline Mineral matter & 12.08 & 11.97 & 11.89 & 13.73 \\
\hline $\mathrm{TDN}^{6}$ & 75.41 & 82.23 & 78.79 & 80.20 \\
\hline $\mathrm{NE}_{\mathrm{I}}^{7}(\mathrm{Mcal} / \mathrm{kg})$ & 2.07 & 2.36 & 2.28 & 2.29 \\
\hline
\end{tabular}

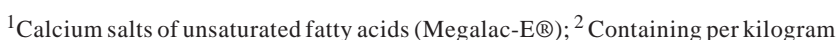
calcium - $120 \mathrm{~g}$; phosphorus - $73 \mathrm{~g}$; sulfur - $30 \mathrm{~g}$; magnesium - $44 \mathrm{~g}$; copper $340 \mathrm{mg}$; zinc - $1.350 \mathrm{mg}$; manganese - $940 \mathrm{mg}$; cobalt - $3 \mathrm{mg}$; iodine - $16 \mathrm{mg}$; selenium - $10 \mathrm{mg}$; iron - $1.064 \mathrm{mg}$; vitamin A - $100.000 \mathrm{IU}$; vitamin D - $40.000 \mathrm{IU}$; vitamin $\mathrm{E}-60 \mathrm{IU} ;{ }^{3} \%$ natural matter; ${ }^{4} \%$ nitrogen insoluble in neutral detergent (\% NT), nitrogen insoluble in acid detergent (\%NT); ${ }^{5}$ Corrected to ash and protein; ${ }^{6}$ Estimated by the equations of NRC (2001); ${ }^{7}$ Net energy lactation estimated by the NRC (2001) equations.

detergent fiber (ADF) contents were obtained according to the method described by Van Soest et al. (1991), using áamilase without addition of sodium sulphite to determine NDF, in Ankon System.

Total carbohydrates (TC) were calculated according to Sniffen et al. (1992), where TC = 100-(\%CP +\%EE + \%MM). The non-fiber carbohydrates contents (NFC) were estimated according to Hall (1998): NFC $=100-[(\% C P$ - \%CP Urea + $\%$ Urea) $+\% \mathrm{EE}+\% \mathrm{MM}+\% \mathrm{NDF}]$. The total digestible nutrients were calculated according to NRC (2001) equations, where: TDN = DNFC + DCP + (DFA * 2.25) + DNDF - 7, in which DFA (digestible fatty acids), DCP, DNFC, DNDF represent the total of digestible nutrients.

The cows were mechanically milked twice a day, at 6:30 a.m. and 3:30 p.m. The milk yield was adjusted to 3.5\% of fat (FCMY), according to Sklan et al. (1992), where
Table 2 - Ingredient and nutrient composition of experimental diets $(\% \mathrm{DM})$

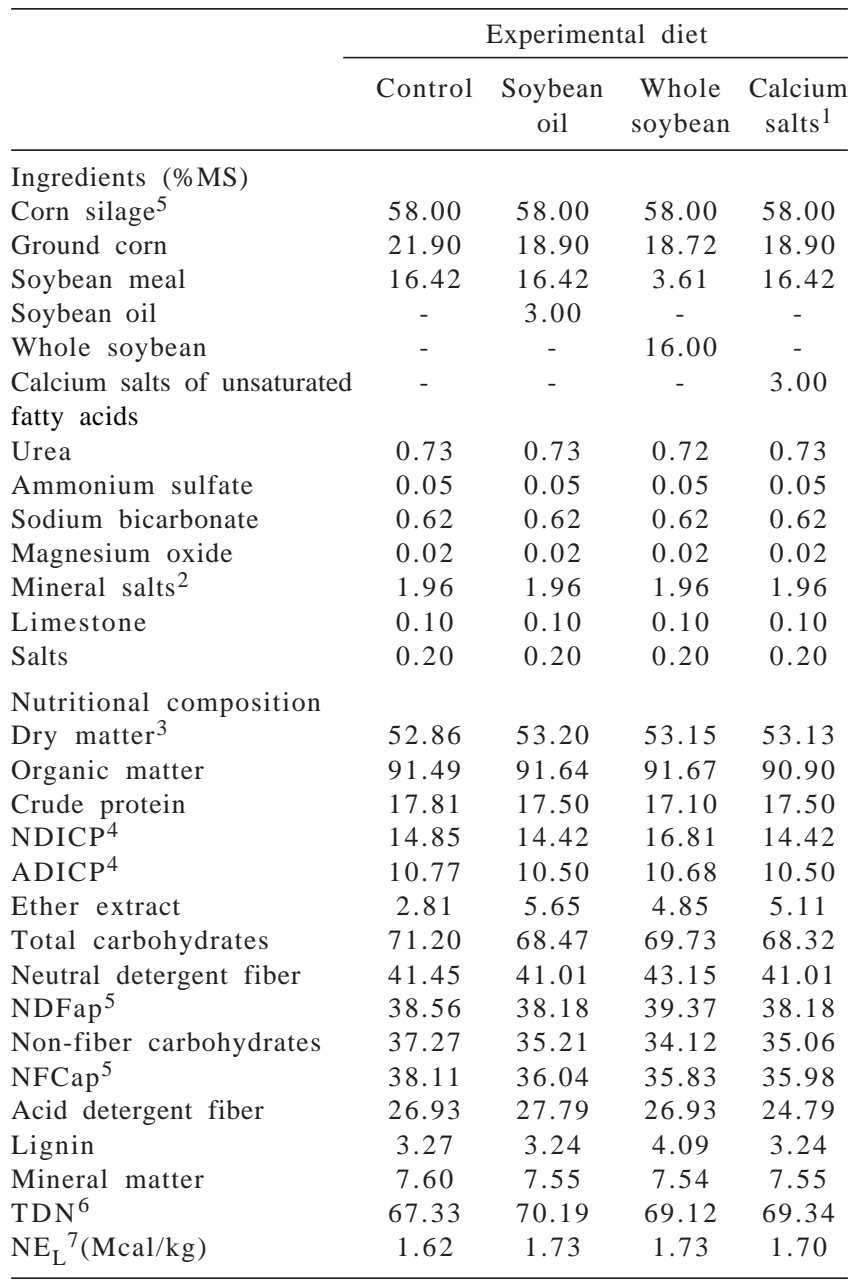

${ }^{1}$ Calcium salts of unsaturated fatty acids (Megalac-E®); ${ }^{2}$ Containing per kilogram: calcium - 120 g; phosphorus - 73 g; sulfur - 30 g; magnesium - 44 g; copper $340 \mathrm{mg}$; zinc - $1.350 \mathrm{mg}$; manganese - $940 \mathrm{mg}$; cobalt - $3 \mathrm{mg}$; iodine - $16 \mathrm{mg}$; selenium - $10 \mathrm{mg}$; iron - $1.064 \mathrm{mg}$; vitamin A - $100.000 \mathrm{IU}$; vitamin D - $40.000 \mathrm{IU}$; vitamin E - $60 \mathrm{IU} ;{ }^{3} \%$ natural matter; ${ }^{4} \%$ nitrogen insoluble in neutral detergent (\% NT), nitrogen insoluble in acid detergent (\%NT); ${ }^{5}$ Corrected to ash and protein; ${ }^{6}$ Estimated by the equations of NRC (2001); ${ }^{7}$ Net energy lactation estimated by the NRC (2001) equations.

$\mathrm{FCMY}=(0.432+0.1625 *$ milk fat content $) * \mathrm{MY}$, and the net energy for lactation was calculated according to NRC equations (2001).

The samples used to analyze milk composition were obtained from the $13^{\text {th }}$ and $16^{\text {th }}$ day of each experimental period by collecting $50 \mathrm{~mL}$ of milk in the milking equipment coupled jar, being each sample composed from the two daily milking. Analysis of total nitrogen (TN), non-protein nitrogen and non-casein nitrogen in the milk, were made at the Laboratório de Tecnologia de Produtos de Origem Animal from the Departamento de Nutrição e Produção Animal, at FMVZ-USP.

The fractions of non-casein nitrogen and milk casein were determined by using the methodology described by Lynch \& Barbano (1998). Milk casein was precipitated in $\mathrm{pH}=4.6$ using acetic acid and sodium acetate solution. 
After precipitation, casein was separated by filtration and concentration of filtrated nitrogen (NNC), determined by Kjeldahl method.

The determination of non-protein nitrogen was performed by Kjeldahl method (AOAC, 1995), after previous preparation of milk samples, using the trichloroacetic acid at $15 \%$ for coagulation of all milk proteins that were removed by filtration, and the filtrated was submitted to analyses.

After the determination of non-protein nitrogen concentration, it was subtracted from the total nitrogen concentration, and in this way, the true protein concentration was determined. Casein concentration was determined by subtracting non-casein nitrogen from total nitrogen (TN). The serum protein was determined through the subtraction of casein content from the milk true protein. Milk crude protein content was calculated by multiplying total nitrogen by 6.38, according to Barbano \& Clark (1990).

The data obtained was submitted to analyses of variance and to the average test (Tukey) with 5\% of significance, using the SAS program (SAS, 1999).

\section{Results and Discussion}

The dry matter and energy intake was similar $(\mathrm{P}>0.05)$ among the control diets and those supplemented with fat sources, with the exception of the animals kept in the diet containing calcium salts of fatty acids, which had lower $(\mathrm{P}<0.05)$ dry matter and nutrients intake (Table 3$)$. The intake of crude protein, total carbohydrates and nonfiber carbohydrates were reduced $(\mathrm{P}<0.05)$ for the experimental diets with additional fat sources in relation to the control diet.

These changes in nutrients intake among the diets with fat sources and the control diet are results from few changes in the chemical composition of the supplied diets, together with the maintenance of dry matter intake, and it can be confirmed by the low coefficients of variation obtained. There was no adverse effect in when using fat sources on the intake, with the exception of the diet with calcium salts of fatty acids, whose reduction can be justified by the poor acceptability of the diet.

When fed with the calcium salts of fatty acids diet, the animals showed lower nutrients intake and, when fed with the soybean oil diet, there was a higher ether extract intake $(\mathrm{P}<0.05)$ in comparison to the whole raw soybean and calcium salts of fatty acid diets. This difference could be explained by the reduction in intake, caused by the lower acceptability of whole raw soybean and calcium salts of unsaturated fatty acids in relation to soybean oil, and by the lower content of this nutrient in the diets.

The neutral detergent fiber intake was close to $1.2 \%$ of the body weight recommended by Mertens (1994) for optimum dry matter intake in lactating cows.

Allen (2000) evaluated several experiments with diets containing fat sources for cows in lactation and observed that diets with calcium salts of fatty acids have greater reduction in intake, justified by the lower acceptability of this fat source in comparison to other fat sources, like oils, oilseeds and animal fat. Moallem et al. (2007) also observed lower intake by cows supplemented with calcium salts of unsaturated fatty acids in comparison to other fat sources. According to NRC (2001), usually, the addition of calcium salts of fatty acids in diets for dairy cows result in linear decrease of dry matter intake. However, in studies evaluating intake by using supplementation of different fat sources, it has been observed maintenance and, in some cases, increase of intake. These results are attributed to the low heat increase of fat in periods of heat stress, or to the reduction

Table 3 - Means and coefficient of variation for the intake of nutrients obtained for the experimental diets

\begin{tabular}{|c|c|c|c|c|c|c|}
\hline \multirow[t]{2}{*}{ Variable } & \multicolumn{4}{|c|}{ Experimental diet } & \multirow[t]{2}{*}{ Mean } & \multirow[t]{2}{*}{ CV $(\%$} \\
\hline & Control & Soybean oil & Whole soybean & Calcium salts ${ }^{1}$ & & \\
\hline \multicolumn{7}{|l|}{ Intake (kg/day) } \\
\hline Dry matter & $17.73 a$ & $16.84 \mathrm{ab}$ & $16.68 \mathrm{ab}$ & $15.99 b$ & 16.81 & 5.73 \\
\hline Organic matter & $16.30 \mathrm{a}$ & $15.15 \mathrm{ab}$ & $15.32 \mathrm{ab}$ & $14.74 b$ & 15.46 & 4.98 \\
\hline Crude protein & $3.22 \mathrm{a}$ & 3.01b & $2.92 b$ & 2.91b & 3.01 & 5.23 \\
\hline Extract ether & $0.51 \mathrm{c}$ & $0.98 a$ & $0.83 \mathrm{~b}$ & $0.84 \mathrm{~b}$ & 0.79 & 6.07 \\
\hline Neutral detergent fiber & $7.26 a$ & $6.78 \mathrm{bc}$ & 7.13ab & $6.46 \mathrm{c}$ & 6.91 & 6.09 \\
\hline Non-fiber carbohydrates & $7.04 \mathrm{a}$ & $6.36 \mathrm{~b}$ & $6.03 \mathrm{~b}$ & $6.07 \mathrm{~b}$ & 6.38 & 5.15 \\
\hline Total digestible nutrients (kg/day) & $12.17 \mathrm{a}$ & $12.10 \mathrm{ab}$ & $11.68 \mathrm{ab}$ & $11.38 b$ & 11.83 & 5.45 \\
\hline Dry matter (\%BW) & $3.28 \mathrm{a}$ & $3.11 \mathrm{ab}$ & $3.11 \mathrm{ab}$ & $3.08 \mathrm{~b}$ & 3.13 & 5.77 \\
\hline Neutral detergent fiber (\%BW) & $1.33 \mathrm{a}$ & $1.24 \mathrm{ab}$ & $1.32 \mathrm{a}$ & $1.19 b$ & 1.27 & 6.50 \\
\hline Net energy of lactation (Mcal/kg) & 28.23 & 28.39 & 28.27 & 27.04 & 27.98 & 7.48 \\
\hline
\end{tabular}

${ }^{1}$ Calcium salts of unsaturated fatty acids $\left(\right.$ Megalac- $\left.E^{\circledR}\right)$.

Means followed by same letter in the same row do not differ $(\mathrm{P}>0.05)$ by Tukey test. 
of propionate production when the fat source replaced the grains in the diets (NRC 2001).

When the different fat sources in diets of milk cows were evaluated, different answers related to the type and level of inclusion of fat supplements in the diet are expected. The addition of tallow, yellow grease and calcium salts of fatty acids also result in negative effect with a linear decrease of this variable. Moreover, variations of intake, followed by the decrease in fat milk content and reduction of ruminal digestion of fiber, are indicators that there was an alteration in ruminal fermentation and in the intake with addition of fat to the diet.

Although there are studies about the use of fat for lactating cows, the mechanisms by which this supplementation influences intake are not fully elucidated, but there are strong evidences that the effect of fat on ruminal fermentation, intestinal motility, acceptability of diet with supplement, liberation of intestinal hormones, regulatory mechanisms that control food intake and the limited capacity of ruminants to oxide fatty acids are the main reasons for the inhibition of intake (Allen, 2000).

No effect $(\mathrm{P}>0.05)$ of the dietary fat sources on the corrected milk yield, or on the protein, lactose, total dry extract and non-fat extract content and somatic cells count (Table 4) was observed. However, when fed the diet with the whole raw soybean as the fat source, the cows showed lower $(\mathrm{P}<0.05)$ milk yield.

The utilization of calcium salts of fatty acids as fat source in the diet resulted in lower $(\mathrm{P}<0.05)$ milk fat content. This result can be justified by the lower intake when compared to the one obtained in the control diet. It is likely that the diet with calcium salts of fatty acids (Megalac- E) resulted in lower production and availability of volatile fatty acids to milk fat synthesis. It is also possible that there was a reduction in fiber digestibility and/or formation of intermediate fatty acids during ruminal biohydrogenation, that could have influenced milk fat synthesis in the mammary gland (Palmquist \& Jenkins, 1980; Chalupa et al., 1984).

The animals showed lower protein production in comparison to the other experimental diets because the whole raw soybean based diet resulted in lower milk yield and did not alter protein content. Vargas et al. (2002) and Duarte et al. (2005) verified similar results when using whole raw soybean as fat source to evaluate milk production and composition. The lower milk production observed with the whole raw soybean based diet can be related to the lower utilization of nutrients and the reduction of dry matter digestibility, with consequently lower available energy, while the reduction in intake when cows were fed with calcium salt in comparison to the control diet and to the soybean oil diet, can be related to the acceptability of this diet by the animals (Allen, 2000; NRC 2001).

The productive efficiency did not differ $(\mathrm{P}>0.05)$ among the control, soybean oil and calcium salt diets. However, the diet with whole raw soybean resulted in lower productive efficiency in comparison to the other experimental diets, with the exception of the control diet. This result can be attributed to the lower milk production and the maintenance of the level of milk production; however the corrected milk production was equal in all experimental diets. Therefore, it

Table 4 - Effect of experimental rations on milk yield and composition, production efficiency, body weight, the change in body weight, body condition score and change in body condition score

\begin{tabular}{|c|c|c|c|c|c|c|}
\hline \multirow[t]{2}{*}{ Variable } & \multicolumn{4}{|c|}{ Experimental diet } & \multirow[t]{2}{*}{ Mean } & \multirow[t]{2}{*}{ CV (\%) } \\
\hline & Control & Soybean oil & Whole soybean & Calcium salts ${ }^{1}$ & & \\
\hline Milk yield (kg/day) & $26.62 \mathrm{a}$ & $26.37 \mathrm{a}$ & $24.13 b$ & $25.70 \mathrm{ab}$ & 25.70 & 7.10 \\
\hline Fat corrected milk ${ }^{2}$ (kg/day) & 24.50 & 24.41 & 23.13 & 23.25 & 23.82 & 8.00 \\
\hline Productive efficiency ${ }^{3}$ (kg/kg) & $150 \mathrm{ab}$ & $1.57 \mathrm{a}$ & $1.44 \mathrm{~b}$ & $1.61 \mathrm{a}$ & 1.53 & 6.90 \\
\hline Fat $(\%)$ & $307 a b$ & $2.96 a b$ & 3.35a & $2.83 b$ & 3.05 & 12.15 \\
\hline Fat (kg/day) & 0.81 & 0.78 & 0.78 & 0.70 & 0.77 & 13.44 \\
\hline Protein (\%) & 2.82 & 2.82 & 2.84 & 2.78 & 2.82 & 3.09 \\
\hline Protein (kg/day) & $0.75 a$ & $0.74 \mathrm{a}$ & $0.68 b$ & $0.71 \mathrm{a}$ & 0.72 & 8.59 \\
\hline Lactose (\%) & 4.53 & 4.52 & 4.53 & 4.50 & 4.53 & 3.63 \\
\hline Lactose (kg/day) & 1.18 & 1.17 & 1.08 & 1.15 & 1.15 & 8.86 \\
\hline Total solids $(\%)^{3}$ & 11.21 & 10.91 & 11.30 & 10.82 & 11.06 & 5.42 \\
\hline Solids $(\%)^{4}$ & 8.18 & 8.09 & 8.10 & 7.95 & 8.28 & 3.68 \\
\hline Somatic cell count $(1.000 / \mathrm{mL})$ & 151.33 & 194.33 & 261.58 & 309.08 & 229.00 & 80.66 \\
\hline Weigth body (kg) & 543.50 & 548.08 & 535.96 & 531.83 & 539.84 & 3.08 \\
\hline Body weight change (kg) & $-6.67 b$ & $0.92 \mathrm{ab}$ & $3.08 \mathrm{ab}$ & $1.92 \mathrm{a}$ & -1.73 & - \\
\hline Body condition score & 2.73 & 2.75 & 2.73 & 2.73 & 2.73 & 4.42 \\
\hline Body condition score change & -0.04 & -0.04 & -0.08 & -0.04 & -0.01 & - \\
\hline
\end{tabular}

${ }^{1}$ Calcium salts of unsaturated fatty acids (Megalac- $\left.\mathrm{E}^{\circledR}\right)$; ${ }^{2}$ Milk yield corrected to $3.5 \%$ of gordura; ${ }^{3} \mathrm{PE}=$ yield production $(\mathrm{kg} / \mathrm{day}) / \mathrm{dry}$ matter intake $(\mathrm{kg} / \mathrm{day})$.

Means followed by same letter in the same row do not differ $(\mathrm{P}>0.05)$ by Tukey test. 
is possible that the utilization of nutrients was lower for animals that consumed this diet.

The protein:fat ratio of this study showed average values ranging from 0.85 to 0.95 for the experimental diets, which is similar to the usual values in the literature, that vary from 0.85 to 0.90 (Carvalho et al., 1999).

There was no effect of experimental diets on the somatic cell count (SCC) and the on changes of body weight and on body condition score. The body weight and the body condition score were not influenced $(\mathrm{P}>0.05)$ by the experimental diets (Table 5) and this confirms that the diets supplied the nutritional demand of the animals during the experimental period, preventing body reserve mobilization to attend the energy demands, although the cows were in the mid-lactation and with positive energy balance. It is necessary to emphasize that, although milk production for the whole raw soybean and calcium salts based diets was different, the body weight and the body condition score did not vary.

There was no effect $(\mathrm{P}>0.05)$ in the utilization of fat sources in the diet on the protein, non-protein nitrogen and non-casein nitrogen, casein, casein/true protein and serum protein contents (Table 5). Similarly, there was no alteration on the proportions of protein milk fractions, based on the total protein content.

These results can be considered of great importance for the industry, primarily when the contents of casein and casein based on crude protein are observed. Although milk protein contents were relatively low, the elevation of total milk protein would not be advantageous in terms of industrial yield in cheese fabrication, once high yield of this dairy product depends on high milk casein concentration (Block, 2000).
The effect of increasing milk production on milk protein content in lactating cows receiving fat supplementation in the diet, according to literature, is correlated to the dilution of total solids, reducing milk protein. Wu \& Hurber (1993) reviewed data from 49 experiments with 83 comparisons among diets with and without addition of fat in dairy cows and observed that, in most cases, the protein content was reduced according to the level of addition of fat sources in the diet.

DePeters et al. (1987) verified that the addition of fat in diets promoted a reduction in casein content and increased the non-protein nitrogen content, while the serum nitrogen increased among cows receiving low amount of fat in the diet. In this study, the fat sources used in diets did not affect the concentrations of milk protein fractions, probably due to the differences in the basal composition of the diet used, especially corn silage, to the level and characteristics of fat sources used in diets, as well as to the level of production and the stage of lactation of the evaluated animals.

The results were similar to the ones obtained by Perfield et al. (2002) who evaluated the milk protein fractions of cows supplemented with calcium salts of fatty acids in diet, and did not observe effect of fat supplementation on the composition of milk protein fractions. Drackley et al. (1994) evaluated the milk protein fraction from Holstein and Jersey cows in mid-lactation receiving diets with addition of fat sources and verified that the casein content, in both breed, did not differ between control diets and diets with fat sources. The serum protein content and the non-protein nitrogen tended to be lower for cows receiving fat in the diet in comparison to the control diet. Khorasani et al. (1991) verified increase in casein and true protein content when

Table 5 - Means and coefficient of variation (CV) for crude protein, non-protein nitrogen, non-casein nitrogen, true protein, casein, the casein: true protein, whey protein obtained with the experimental diets

\begin{tabular}{|c|c|c|c|c|c|c|}
\hline \multirow[t]{2}{*}{ Variable } & \multicolumn{4}{|c|}{ Experimental diet } & \multirow[t]{2}{*}{ Mean } & \multirow[t]{2}{*}{ CV (\%) } \\
\hline & Control & Soybean oil & Whole soybean & Calcium salts ${ }^{1}$ & & \\
\hline Crude protein (\%) & 2.82 & 2.82 & 2.84 & 2.78 & 2.82 & 3.09 \\
\hline Non-protein nitrogen (\%) & 0.185 & 0.199 & 0.194 & 0.205 & 0.19 & 10.45 \\
\hline Non-protein nitrogen (\%CP) & 6.62 & 7.12 & 6.89 & 7.37 & 6.99 & 10.83 \\
\hline Non-casein nitrogen (\%) & 0.59 & 0.62 & 0.60 & 0.60 & 0.60 & 8.77 \\
\hline Non-casein nitrogen (\%CP) & 21.02 & 22.05 & 21.42 & 21.69 & 21.54 & 8.26 \\
\hline True protein (\%CP) & 93.31 & 92.45 & 93.11 & 93.71 & 93.14 & 2.27 \\
\hline Casein $(\%)$ & 2.23 & 2.18 & 2.23 & 2.18 & 2.21 & 4.42 \\
\hline Casein (\%CP) & 78.97 & 77.29 & 78.48 & 78.29 & 78.26 & 2.62 \\
\hline Casein/TP & 0.85 & 0.84 & 0.84 & 0.84 & 0.84 & 3.63 \\
\hline Whey protein (\%) & 0.40 & 0.42 & 0.41 & 0.42 & 0.42 & 21.30 \\
\hline Whey protein (\%CP) & 0.14 & 0.15 & 0.15 & 0.15 & 0.15 & 20.67 \\
\hline
\end{tabular}

${ }^{1}$ Calcium salts of unsaturated fatty acids (Megalac-E®).

Means followed by same letter in the same row do not differ $(\mathrm{P}>0.05)$ by Tukey test. 
increasing levels of fat in the diet were supplied, and also verified a tendency to increase the non-protein nitrogen content in cows supplemented with fat.

Smith et al. (1978) emphasized that the reduction in milk protein content in some studies with the use of fat can be explained by the reduction in the utilization of glucose, consequence of the reduction in the ruminal propionate concentration, causing low concentration of insulin in the plasma.

\section{Conclusions}

The utilization of fat sources in diets alters the intake and the productive performance of lactating cows and the response depends on the fat source used. However, the utilization of these sources in diets does not influence the composition of milk protein fraction.

\section{Acknowledgments}

The authors thank Mr. Antonio Carlos Bueno Silva, staff of the Laboratório de Pesquisa em Bovinos de Leite, Mr. José Franchini Garcia Moreno and Mrs. Lucinéia Mestieri, staff of the Laboratório de Tecnologia de Produtos de Origem Animal, and Mr. Ari Luiz de Castro, Mr. Gilson Luiz Alves de Godoy and Mrs. Simi Luiza Durante Aflalo Robassini, technicians of Laboratório de Nutrição Animal do Departamento de Nutrição e Produção Animal da FMVZ-USP of FMVZ-USP, for the indispensable help conducting the experiment and realizing the laboratorial analyses.

\section{References}

ALLEN, M.S. Effects of diet on short-term regulation of feed intake by lactating dairy cattle. Journal of Dairy Science, v.83, n.7, p.1598-1630, 2000.

ASSOCIATION OF OFFICIAL ANALYTICAL CHEMISTS - AOAC. Official methods of analysis. 11.ed. Washington, 1995. 1050p.

BARBANO, D.M.; CLARK, J.L. Kjeldahl method for determination of total nitrogen content of milk: collaborative study. Journal AOAC International, v.73, n.6, p.849-859, 1990

BLOCK, E. Nutrição de vacas leiteiras e composição do leite. In: SIMPÓSIO INTERNACIONAL SOBRE QUALIDADE DO LEITE, 2., 2000, Curitiba. Anais... Curitiba, 2000. p.85-88.

CARVALHO, M.P.; FONSECA, L.F.L.; PEREIRA, C.C. Manipulação nutricional da composição do leite: proteína e gordura. In: SIMPÓSIO INTERNACIONAL SOBRE PRODUÇÃo INTENSIVA DE LEITE, 4., Caxambu. Anais... Caxambu: Instituto Fernando Costa, 1999. p.29-35.

CHALUPA, W.; RICKABAUGH, B.; KRONFELD, D.S. et al. Rumen fermentation in vitro as influenced by long chain fatty acids. Journal of Dairy Science, v.67, n.9, p.1439-1444, 1984.

CHILLIARD, Y. Dietary fat and adipose tissue metabolism in ruminants, pigs, and rodents: a review. Journal of Dairy Science, v.76, n.12, p.3897-3931, 1993.
DePETERS, E.J.; TAYLOR, S.J.; FINLEY, C.M. et al. Dietary fat and nitrogen composition of milk from lactating cows. Journal of Dairy Science, v.70, n.6, p.1192-1201, 1987.

DRACKLEY, J.K.; GRUM, D.E.; McCOY, G.C. et al. Comparison of three methods for incorporation of liquid fat into diets for lactating dairy cows. Journal of Dairy Science, v.77, n.3, p.1386-1398, 1994.

DUARTE, L.M.D.; STUMPF JR., W.; FISCHER, V. et al. Efeito de diferentes fontes de gordura na dieta de vacas Jersey sobre o consumo, a produção e a composição do leite. Revista Brasileira de Zootecnia, v.34, n.6, p.2020-2028, 2005.

GARNSWORTHY, P.C. Fat in dairy cow diets. In: GARNSWORTHY, P.C.; WISEMAN, J. (Eds.) Recent developments in ruminant nutrition 4.ed. Nottingham, 2002. p.399-444.

HALL, M.B. Making nutritional sense of nonstructural carbohydrate, In: ANNUAL FLORIDA RUMINANT NUTRITION SYMPOSIUM, 9., 1998, Gainsville, Florida. Proceedings... Gainsville: Florida University Press, 1998. p.108-121.

KHORASANI, O.R.; ROBINSON, P.H.; DE BOER, O. et al. Influence of canola fat on yield, fat percentage, fatty acid profile, and nitrogen fractions in Holstein milk. Journal of Dairy Science, v.74, n.6, p.1904-1911, 1991.

LYNCH, J.M.; BARBANO, D.M. Indirect and direct determination of the casein content of milk by kjeldahl nitrogen analysis: collaborative study. Journal AOAC International, v.81, n.4, p.763-774, 1998.

MERTENS, D.R. Regulation of forage intake. In: FAHEY, G.C.; COLLINS, M.; MERTENS, D.R. et al. (Eds.). Forage quality evaluation and utilization. Madison: ASA. CSSA, SSSA, 1994. p.450-493.

MOALLEM, U.; KATZ, M.; ARIELI, A. et al. Effects of peripartum propylene glycol or fats differing in fatty acid profiles on feed intake, production, and plasma metabolites in dairy cows. Journal of Dairy Science, v.90, n.8, p.3846-3856, 2007.

NATIONAL RESEARCH COUNCIL - NRC. Nutrient requirements of dairy cattle. 7.ed. Washington, D.C.: National Academic Press, 2001. 381p.

PALMQUIST, D.L.; JENKINS, T.C. Fat in lactation rations: Review. Journal of Dairy Science, v.63, n.1, p.1-14, 1980.

PERFIELD, J.W.; BERNAL-SANTOS, G.; OVERTON, T.R. et al. Effects of dietary supplementation of rumen-protected conjugated linoleic acid in dairy cows during established lactation1. Journal of Dairy Science, v.85, n.10, p.2609-2617, 2002.

SANTOS, A.D.F.; TORRES, C.A.A.; RENNÓ, F.P. et al. Utilização de óleo de soja em rações para vacas leiteiras no período de transição: consumo, produção e composição do leite. Revista Brasileira de Zootecnia, v.38, n.7, p.1363-1371, 2009.

SAS/STAT User's guide. Release 8.0 Edition. Cary: [s.n.], 1999. $1500 \mathrm{p}$.

SILVA, D.J.; QUEIROZ, A.C. Análise de alimentos: métodos químicos e biológicos. Viçosa, MG: Universidade Federal de Viçosa, 2002. 235p.

SKLAN, D.; ASHKENAZI, R.; BRUN, A. et al. Fatty acids, calcium soaps of fatty acids, and cottonseeds fed to high yielding cows. Journal of Dairy Science, v.75, n.9, p.2463-2472, 1992.

SMITH, N.E.; DUNKLEY, W.L.; FRANKE, A.A. Effects of feeding protected tallow to dairy cows in early lactation.Journal of Dairy Science, v.61, n.5, p.747, 1978.

SMITH, W.A.; HARRIS, B.; VAN HORN JR., H.H. et al. Effects of forage type on production of dairy cows supplemented with whole cottonseed, tallow, and yeast. Journal of Dairy Science, v.76, n.1, p.205-215, 1993.

SNIFFEN, C.J.; O'CONNOR, J.D.; VAN SOEST, P.J. et al. A Net carbohydrate and protein system for evaluating cattle diets. Journal of Animal Science, v.70, n.12, p.3562-3577, 1992. 
STAPLES, C.R.; THATCHER, W.W.; MATTOS, R. Fa supplementation strategies for lactating dairy cow diets. In: SIMPÓSIO INTERNACIONAL DE BOVINOCULTURA DE LEITE, 2., 2001, Lavras. Anais... Lavras: UFLA, 2001. p.161-178.

VAN SOEST, P.J.; MASON, V.C. The influence of Maillard reaction upon the nutritive value of fibrous feeds. Animal Feed Science and Technology, v.32, n.1, p.45-53, 1991.

VARGAS L.H.; LANA, R.P.; JHAM, G.N. et al. Adição de lipídios na ração de vacas leiteiras: parâmetros fermentativos ruminais, produção e composição do leite. Revista Brasileira de Zootecnia, v.31, n.1, p.522-529, 2002.

WU, J.T.; HUBER, S.C.; CHAN, J.M. et al. Effect of source and amount of supplemental fat on lactation and digestion in cows. Journal of Dairy Science, v.77, n.6, p.1644-1651, 1994.

WU, Z.; HUBER, J.T. Relationship between dietary fat supplementation and milk protein concentration in lactating cows: a review. Livestock Production Science, v.39, n.2, p.141-155, 1993. 